See discussions, stats, and author profiles for this publication at: https://www.researchgate.net/publication/339578355

\title{
Comparative Study of Single- and Double-Layer BaFe12O19-Graphite Nanocomposites for Electromagnetic Wave Absorber Applications
}

Article in Materials Research Bulletin · February 2020

DOI: 10.1016/j.materresbull.2020.110843

\section{CITATIONS}

11 authors, including:

Ismayadi Ismail

Universiti Putra Malaysia

167 PUBLICATIONS 831 CITATIONS

SEE PROFILE

Khamirul Amin Matori

2. Universiti Putra Malaysia

229 PUBLICATIONS 1,935 CITATIONS

SEE PROFILE

Some of the authors of this publication are also working on these related projects:

superconductor View project

Project Gas Sensor View project

\section{READS}

76

Idza Riati Ibrahim

Universiti Putra Malaysia

81 PUBLICATIONS 328 CITATIONS

SEE PROFILE

Fadzidah Mohd Idris

USIM | Universiti Sains Islam Malaysia

52 PUBLICATIONS 215 CITATIONS

SEE PROFILE 


\title{
Comparative study of single- and double-layer $\mathrm{BaFe}_{12} \mathrm{O}_{19}$-Graphite nanocomposites for electromagnetic wave absorber applications
}

\author{
Ismayadi Ismail $^{\mathrm{a}, *}$, Idza Riati Ibrahim ${ }^{\mathrm{a}}$, Khamirul Amin Matori ${ }^{\mathrm{a}, \mathrm{b}}$, Zaiki Awang ${ }^{\mathrm{c}}$, \\ Muhammad Misbah Muhammad Zulkimi ${ }^{\mathrm{a}}$, Fadzidah Mohd Idris ${ }^{\mathrm{d}}$, Rodziah Nazlan ${ }^{\mathrm{e}}$, \\ Raba'ah Syahidah Azis ${ }^{\mathrm{a}, \mathrm{b}}$, Mohd Hafiz Mohd Zaid ${ }^{\mathrm{b}}$, Siti Nor Ain Rusly ${ }^{\mathrm{a}}$, Mehmet Ertugrul ${ }^{\mathrm{f}}$ \\ ${ }^{a}$ Materials Synthesis and Characterization Laboratory, Institute of Advanced Technology, Universiti Putra Malaysia 43400 UPM Serdang, Selangor, Malaysia \\ ${ }^{\mathrm{b}}$ Department of Physics, Faculty of Science, Universiti Putra Malaysia, 43400 UPM Serdang, Selangor, Malaysia \\ ${ }^{\mathrm{c}}$ Microwave Research Institute, Universiti Teknologi MARA, 40450 Shah Alam, Malaysia \\ ${ }^{\mathrm{d}}$ GENIUS Insan College, Universiti Sains Islam Malaysia, Bandar Baru Nilai, 71800 Nilai, Negeri Sembilan, Malaysia \\ ${ }^{\mathrm{e}}$ Department of Materials Technology, Faculty of Industrial Science and Technology, Universiti Malaysia Pahang, Kampus Gambang, Lebuhraya Tun Razak, Kuantan, \\ Pahang, Malaysia \\ ${ }^{\mathrm{f}}$ Department of Electronics, Engineering Faculty, Ataturk University, 25240 Erzurum, Turkey
}

\section{A R T I C L E I N F O}

\section{Keywords:}

Barium hexaferrite

Reflection loss

Microwave absorbers

\begin{abstract}
A B S T R A C T
The development of stealth technology for military applications and increasing concerns of electromagnetic pollution have garnered interest to design microwave absorbing materials with wide absorption bandwidth and effective absorption properties. Two batches of samples as a potential radar absorbing material were prepared in this study: single-layer and double-layer nanocomposite mixtures of graphite and barium hexaferrite nanoparticles. Characterizations of electromagnetic and microwave absorbing properties were carried out in the frequency range of 8-12 GHz (X-band) and 12-18 GHz ( $\mathrm{K}_{\mathrm{u}}$-band). Single-layer samples with thickness of $2 \mathrm{~mm}$ showed optimal absorption properties with minimum reflection loss of $-20.5 \mathrm{~dB}$ at $11.8 \mathrm{GHz}$ for $\mathrm{X}$-band and $-20.7 \mathrm{~dB}$ at $14.7 \mathrm{GHz}$ for $\mathrm{K}_{\mathrm{u}}$-band, displaying bandwidths of $0.6 \mathrm{GHz}$ for the former and $3.8 \mathrm{GHz}$ for the latter at $-10 \mathrm{~dB}$. On the other hand, double-layer samples made of $1 \mathrm{~mm}$ thick barium hexaferrite matching layer and $2 \mathrm{~mm}$ thick graphite absorbing layer showed optimal absorption properties with minimum reflection loss of $-30.0 \mathrm{~dB}$ at $9.2 \mathrm{GHz}$ for X-band with narrower bandwidth of $0.6 \mathrm{GHz}$. The microwave absorption properties of these nanocomposites were attributed to combined effect of dielectric loss from graphite and magnetic loss from ferrite.
\end{abstract}

\section{Introduction}

In recent years, the development of stealth technology for military applications and the growing of electromagnetic pollution have garnered interest to design microwave absorbing materials with wide absorption bandwidth and effective absorption properties. To achieve significant absorption, the materials must possess electric and/or magnetic dipoles which interact with the electromagnetic fields of the radiation. Thereby, complex permeability $\left(\mu^{*}=\mu^{\prime}-j \mu^{\prime \prime}\right)$ and permittivity $\left(\varepsilon^{*}=\varepsilon^{\prime}-j \varepsilon^{\prime \prime}\right)$ of materials determine the reflection and attenuation characteristics of electromagnetic wave absorbers.

M-type hexaferrite, particularly $\mathrm{BaFe}_{12} \mathrm{O}_{19}$ is a promising material for permanent magnet, advanced recording, and microwave devices [1] as it possesses many outstanding properties including fairly large magnetization, excellent chemical stability, and corrosion resistivity as compared to other hexaferrites [1,2]. Such properties should be modulated to suit various applications [3]. $\mathrm{BaFe}_{12} \mathrm{O}_{19}$ has been extensively used in the development of potential microwave absorbers in higher GHz range [4-11], particularly owing to its large tunable anisotropy field [11]. Therefore, $\mathrm{BaFe}_{12} \mathrm{O}_{19}$ is selected as one of the microwave absorber components in this study. However, ferrites display reduction of magnetic permeabilities with weak resonance absorption and narrow operating bandwidths at the higher $\mathrm{GHz}$ frequency range.

Alternatively, carbon material is incorporated in microwave absorbing materials. Carbon materials including graphite, graphene, carbon fibre and carbon nanotube are highly of interest as microwave absorber since they are electric loss type microwave absorbers and offer high complex permittivity values, attributing to their superior electric

\footnotetext{
* Corresponding author.

E-mail address: ismayadi@upm.edu.my (I. Ismail).
} 